\title{
Reforms of Mathematics Curriculum Guidelines for Middle Education in Brazil and Paraguay
}

\author{
Marcelo de Oliveira Dias ${ }^{1 \star}$ \\ ${ }^{1}$ Universidade Federal Fluminense, BRAZIL \\ *Corresponding Author: marcelo_dias@id.uff.br \\ Citation: Dias, M. d. O. (2021). Reforms of Mathematics Curriculum Guidelines for Middle Education in Brazil and Paraguay. Pedagogical Research, \\ 6(3), em0096. https://doi.org/10.29333/pr/10950

\section{ARTICLE INFO} \\ Received: 21 Sep. 2020 \\ Accepted: 18 Mar. 2021

\begin{abstract}
The construction of the National Common Curricular Base (NCCB) for the area of Mathematics and its High School Technologies in Brazil and the last update of the Mathematics Program for High School in Paraguay are prescribed curriculum documents in force for the teaching of Mathematics in these countries. The construction of each one of them exposed intense political elements and has been a constant target of conflicts and tensions in these countries. The policy cycle approach, established by sociologist Stephen J. Ball and collaborators, has usually been applied by curriculum policy researchers, as well as from other sectors. Therefore, it has been configured in an important methodological bias for the understanding of the documents' approval processes from the contexts of production and influence, as well as the standards that guided this construction and the ideological constraints that emanate from the involvement of multilateral organisms. In order to achieve this objective, this article presents a comparative analysis of documents in specific circumstances during the processes of the recent reforms of the prescribed documents for mathematical learning in Brazil and Paraguay. It starts from the methodological phases of Comparative Education, summarized by Pilz (2012), by which it reflected on the vertical models and the reductionism and emptying of the area, as well as the contents as instruments of management and performance to meet the varied demands of the globalized world. The theoretical hybridization carried out in the study also pointed to a greater number of specific competences prescribed for the teaching of Mathematics in Brazil, and in Paraguay, a curriculum that prioritizes more functional Mathematics.
\end{abstract}

Keywords: policy cycle, comparative research, mathematical curriculum reforms, middle education in Brazil and Paraguay

\section{INTRODUCTION}

In this article, the objective is to question the recent Curricular Reforms in Mathematics in Brazil and Paraguay, around, particularly, the questions:

(a) What were the contexts of production and influences of documents recently prescribed for the teaching of Mathematics in High School?

(b) What debates, references and ideologies are being put into play in the production processes of Mathematics programs in the reform of High School?

(c) What similarities and specificities can be highlighted in these different reform contexts?

This objective was problematized taking into account the understanding that such prescribed curricular documents highlight perspectives in which an attempt is made to meet the demands of the globalized world, in which multilateral political bodies stimulate these processes, aiming especially at rankings in evaluations.

The understanding of the curriculum prescribed in this text is identical to that of Macedo (2002, p. 171): "[...] a document that legitimizes the school's own existence, even though it is known that the real curriculum goes far beyond the official document [...]". The choice for attempting to compare reforms in High School in Brazil and Paraguay is justified because they are neighboring countries in South America and due to the complex diversity of factors related to the development and development of curricula, specifically that of Mathematics, of which the programs intend to deal with in their educational trajectories.

In this article, this definition and these facts were admitted in order to analyze the contexts and challenges provided by the scenarios of the two countries in the face of the reforms in the prescriptions of Mathematics for the last stage of Basic Education in Brazil, corresponding to High School in Paraguay. That said, it is reiterated that the terms will be used throughout the text as synonyms. 
Initially, designs related to the type of student to be educated are prioritized. Thus, through the treatment of part of the Policy Cycle organized by Ball (1994), a comparative analysis of the contexts of influence, production and literature review regarding the reforms of the recent Mathematical documents in force in Brazil and Paraguay has been accomplished.

\section{EDUCATIONAL CONTEXTS OF THE INVESTIGATED COUNTRIES}

\section{Organization of the Education Systems}

The Education Guidelines and Bases Law (LDB), No. 9,394 / 96, is a result of the current structure of Brazilian education. It is linked to the general guidelines of the Federal Constitution of 1988, as well as to the respective Constitutional Amendments in force.

According to art. 4th of the LDB (Brazil, 2017), Basic Education in Brazil is composed of Early Childhood Education, Elementary Education and High School. In its art. 32, there is that compulsory elementary education takes 9 years and, observing the rules of the education system, these are allowed to break it down into teaching-learning cycles.

In the educational sphere of Paraguay, in 1998, when the General Education Law (No. 1264) was enacted, the general principles of public and private education in the country were established. Since then, Paraguay has made considerable progress in increasing and reaching educational coverage, but efforts to achieve greater equity and educational quality must be maintained. The educational system is free and mandatory from the age of 5, extending to 17.

In the National Education System, formal education is structured on three levels: the first, containing Initial Education (IE), the first and the second cycle of Basic Education (EEB); the second, containing the third cycle of BSE and High School (EM); and the third level, with College Education (ES) (Law No. 5749/17) ${ }^{1}$.

High School consists of a level of formal education aiming at the active inclusion of students in social life and the labor market or their access to higher education. Its duration is three years, with a single cycle consisting of three courses. It became mandatory and free from 2010 on (Paraguay, 2013).

Table 1. Educational systems in Brazil and Paraguay

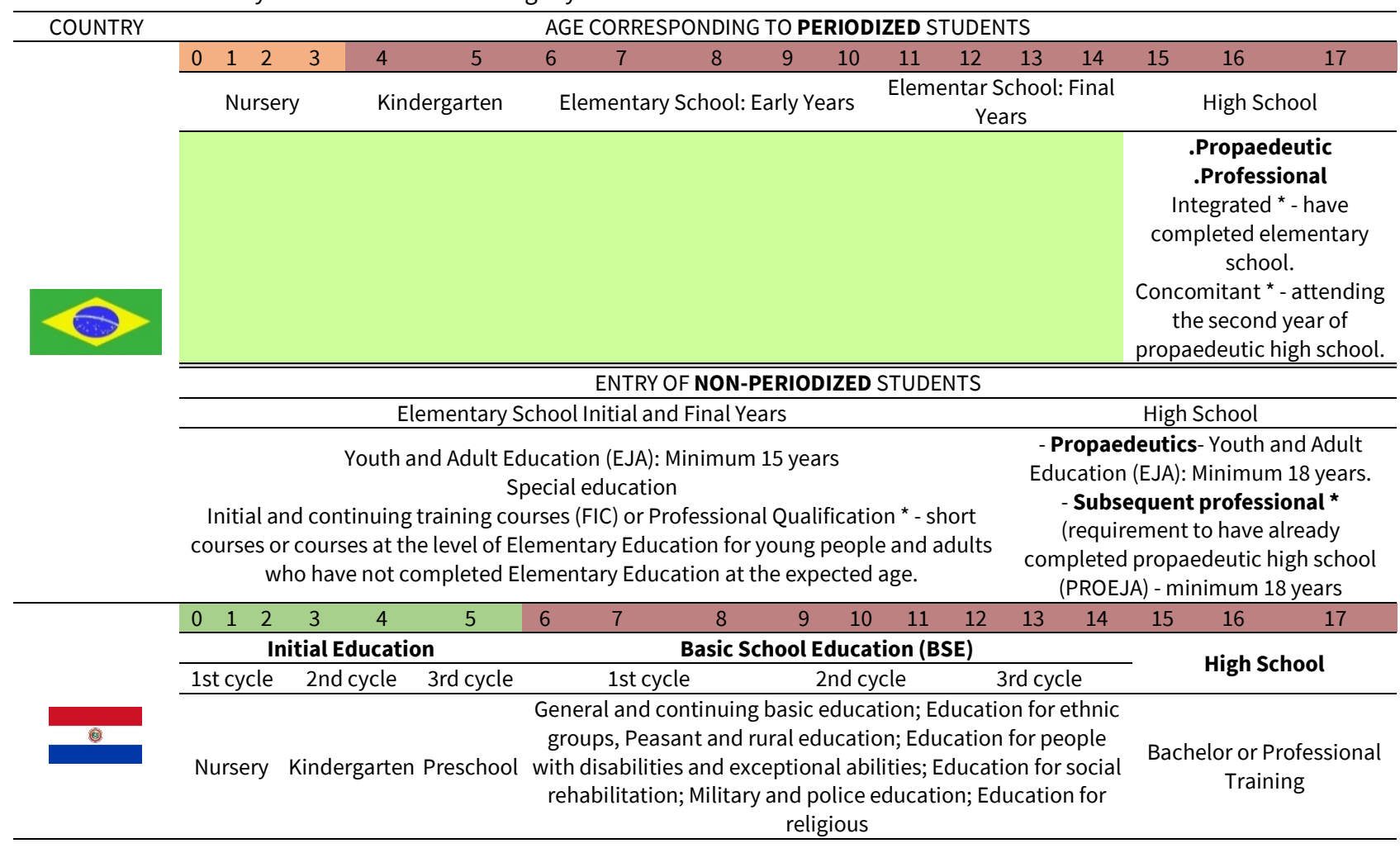

\begin{tabular}{c}
\hline Subtitle: \\
\hline Not Mandatory \\
\hline Mandatory \\
\hline
\end{tabular}

*Professional Qualification Level.

Source: The author

\footnotetext{
${ }^{1}$ Law No. 5749/2017, sanctioned by the Congress of the Paraguayan Nation, which establishes the Organic Charter of the Ministry of Education and Science.
} 
Formerly called Secondary Education, High School has undergone several reforms since the beginning of the 21st century, under the motto "Education, everyone's commitment". The Curricular Reform was gradually implemented in Basic Education from the year 1994, which affected the High School from 2002. From the beginning of its implementation until the moment, adjustments were made with changes more articulated with the evaluation system and with the reorganization of the workload and schedule of the different subjects that are part of the curriculum (Paraguay, 2009).

In the provision of educational systems, similarities are identified regarding the emphasis on general education and the promotion of ethical attitudes and values and the mandatory nature of elementary and secondary education. As specificities, the provision in cycles in Elementary Education is, in Brazil, optional. In Paraguay, this provision is mandatory in Basic School Education. Preschool in Brazil is mandatory, unlike Paraguay, where it is mandatory only from BSE.

In the present study, it should be noted that the reform of regular Basic Education in both countries, of a non-professional nature and qualification, was considered, as they are configured in a mandatory stage. It deals with knowledge known as essential for the area of Mathematics.

\section{METHODOLOGY}

Ferrer (2002) describes the purposes of Comparative Education: (a) illustrating the differences or similarities between countries' educational systems; (b) to present the importance of the contextual factors of these systems as explanatory elements of themselves; (c) situating possible influences they have on certain contextual factors; and (d) contribute to better understanding the system itself through those of other countries.

Gonçalves and Pires (2015, p. 412), as well as other authors, reinforce that "Comparative Education is not reduced to decontextualized cuts and its simplified comparisons, but to research that critically (and qualitatively) analyzes different notions based on conditions social, economic, cultural, political and educational ". Nóvoa (2009) affirms the need for new directions in the area, with a more concrete theoretical basis. Therefore, it is necessary to think about it in terms of New Problems, Analysis Models and Approaches.

For Arnove (2012), the importance of world-systems analysis for the field of Comparative Education, both in terms of consensus and tensions, is reinforced by the centrality of the theme of globalization. For the author, the diffusion of this theme led to:

[...] additional investigations to refine and elaborate the theories and methodologies that will enable scholars, policy makers and practitioners to better understand the multidimensional and transnational trends that shape the functioning and results of educational systems worldwide (Arnove, 2012, p. 149).

Villalobos Torres and Trejo Sánchez (2015), reflecting on the theoretical and methodological bases of Compared Education, point out that it consists of a conceptual and epistemological perspective that aims to analyze the educational phenomenon from an international, supranational or intranational perspective.

For such studies to be effective, significant criteria or the determination of differences must be established by the researcher so that there is the possibility of comparing different realities (Pilz, 2012). Pilz et al. (2016, p. 128) warn that "the interpretation of these comparative results requires caution, since the link between results and explanation is mainly hypothetical at this level".

Based on research by numerous authors, Pilz (2012), which summarizes the methodological phases for carrying out a comparative investigation, adopted: (1st) Descriptive phase - observations and descriptions; (2nd) Explanatory phase - introduces interpretation, in order to explain and understand; (3rd) Juxtaposition phase - first comparison attempt offering the national finding defined in the context of the comparison criteria selected for the side-by-side evaluation and analysis; (4th) Comparative phase - the hypotheses are verified using the systematic comparison, the relations between the countries are analyzed by reference to the comparison criteria and conclusions can be obtained.

Regarding the delimitation of the research method, revisions of official documents and literature were composed, aiming at an appreciation of the speeches that circulated during their reform processes. According to Sharma (2013), this analysis is configured as:

A way to collect qualitative information from a primary or original source of written, printed and recorded materials to answer research questions in interpretive case studies. The documents provide evidence of authentic or real activities carried out in social and human thought organizations (Sharma, 2013, p. 3).

In an attempt to understand the curricular policy impregnated, instruments for the analysis of the policy trajectory (formulation, text production, implementation and results) are offered by Ball's Policy Cycle (1994). Mainardes (2006) characterizes it as:

[...] a continuous cycle consisting of three main contexts: the context of influence, the context of text production and the context of practice. These contexts are interrelated, do not have a temporal or sequential direction and are not linear steps. Each of these contexts presents arenas, places and interest groups and each of them involves disputes and clashes (Mainardes, 2006, p. 5).

The investigation consisted of a documentary analysis of the contexts of Ball's strategies and influences (2004) and a literature review. From this, the following analytical subcategories emerged from the intentions exposed in the reforms of the Mathematics 
for High School programs carried out recently in Brazil and Paraguay: (1) Lines of force of the new programs and (2) Critical points of the new programs.

\section{COMPARATIVE METHOD PHASES}

\section{Descriptive Phase: Contexts of Political Strategies in Recent Curricular Reforms in Brazil and Paraguay}

Interpreted as a set of prescriptions, rules and mechanisms of power, pedagogical discourses must also be considered as an object of analysis. Ball (2013, p. 177), supporting the idea, states: "Therefore, new voices and interests are represented in the political process, and new nodes of power and influence are built and strengthened". In this way, the composition of a policy cycle is being projected embracing new voices, such as those of private entities and international agencies. For them, the construction of curriculum documents is being articulated and financed. Mainardes (2018) warns that:

[...] the context of the political strategy involves the identification of a set of social and political activities that would be necessary to deal with the inequalities created or reproduced by the investigated policy. Therefore, it involves a purposeful exercise based on research data and findings (Mainardes, 2018, p. 14).

The analysis and meditation on educational policies lead to contradictory terrains, involving heuristic technologies and resources. In order to understand its architecture and real intentions, it is necessary to understand the processes and contexts in which these policies were developed. Their nature is not insignificant, as it reflects the political contexts in which they were produced (Ball, 1994).

\section{Contexts of reforms influences}

The context of influence (Ball, 1994) runs through the way in which the process of building the NCCB was managed and approved based on public policies. In the view of Mainardes, it was constituted (2006):

Spaces where political discourses are constructed. It is in this context that interest groups compete to influence the definition of the social purposes of education and what it means to be educated [...]. It is also in this context that the concepts acquire legitimacy and form a basic discourse for politics (Mainardes, 2006, p. 51).

Confirming Passos and Nacarato (2018, p. 125), in Brazil "there is no way to highlight the influence of the World Bank and the Organization for Economic Cooperation and Development (OECD) in public policies aimed at Education". Aside from the Commission convened by the MEC, composed of representatives from Universities, the establishment of partnerships with groups of private entities was evident. Most of the intervention of these entities in the Movement for the National Common Base ${ }^{2}$ (MNCB) are represented by business interests, foundations and philanthropic institutions, such as Lemann Foundation, Natura Institute, Ayrton Senna Institute, Unibanco Institute and others. These are usually those financed by the allocation of taxes from macrocorporations.

In mapping carried out by Avelar and Ball (2017, p. 9), it was concluded that the group formed for the elaboration of the NCCB text is made up of "[...] a network of people and organizations somewhat worn, a speech community focused on the need for educational reform, composed of political entrepreneurs, traveling technocrats and 'thought leaders', as solutions to the problems of educational policy “.

Implicitly, this composition proves that the purpose of implementing the reform was based on the performativity model for success. In Ball's view (2010, p. 38), "performances - of individual subjects or organizations - serve as measures of productivity or results, as ways of presenting quality or moments of promotion or inspection".

Corrêa and Morgado (2018, p. 7) point to foreign curricula that served as a reference for Brazil, alerting the need for:

[...] to point out that the proposed national curriculum model focuses on the models already assumed by the Ministry of Education and Culture (MEC) and MNCB, having as reference the Australian curriculum and the analyzes prepared by The Curriculum Foundation (United Kingdom), ACARA Foundation (Australia) and Yale University (USA).

Recent transnational policies operate in networks, minimizing the role of the State with an arsenal alluding to efficiency. It is a process permeated by speeches that arouse the eyes of agents of curricular reforms with the promise of contemporaneity through the perspective of a supposed privatist "superiority". Proving Corrêa and Morgado (2018, p. 8), this superiority "lies in the fact that international experiences and references from private education groups, which produce the false idea of reliability, effectiveness and efficiency in the construction of other curriculum models in different countries".

Regarding educational reform in Paraguay, studies like Ortiz's (2012, p. 63-64) have highlighted that:

[...] different interests and actors involved played a decisive role in the implementation of the reform. More precisely, they are investment strategies that concretize the relations between the agents and their interests, as well as their weight in the Paraguayan social space. These strategies reveal the position of each one in society, particularly through the volume

\footnotetext{
${ }^{2}$ http://movimentopelabase.org.br/
} 
and structure of capitals, as well as taking a position in relation to the changes that occurred in the field of national education.

On the current situation of the Paraguayan education system, Portillo and Paradeda (2016, p. 15) warn that:

At the current stage, assessment policies have been strengthened and constitute the programmatic axis in the field of education, where assessment in its different forms (standardized assessment of students, assessment of teacher performance and institutional assessment) forms the core of the "guarantee" policies quality of education", as can be seen in the Educational Agenda 2013-2018. In this last period, the country strengthened this line, starting its participation in the PISA Development Test (PISA - D), an adaptation of the widely disseminated and also questioned PISA, prepared by the OECD, which seeks its expansion in poor countries like Paraguay and which has a great impact on the definition of parameters, parameters are measured and valued in international education systems.

Still, it is highlighted by the authors that "[...] it can be noted that Paraguay, like other Latin American countries, has been under the influence of neoliberal policies since the 1990s, a results-based management model and evaluation as a fundamental device to measure the 'products' of the educational system" (Portillo \& Paradeda, 2016, p. 86).

In both countries - and in other nations - curriculum reforms tend to continue to be subject to international influences, involving organizations such as the International Student Assessment Program (PISA), with a focus on mathematical literacy, and the OECD.

The "Future of Education and Capabilities 2030", an OECD project, is currently underway, addressing "technologies that have not yet been invented, and [in] solving social problems that have not yet been anticipated" (OECD, 2018, p. 1). There is also talk of granting supposed support to countries in addressing common challenges in implementing curricula and in identifying critical success factors.

\section{Production context of recent programs}

Dias (2016, p. 39) warns that "the researcher cannot do without satisfactorily knowing the political situation that led to the production of a certain document". Mainardes (2006, p. 5 apud BOWE et al., 1992) adds that "political texts are the result of disputes and agreements, as groups that operate within different places of the production of texts compete to control representations of politics". Thus, in a brief description, legal aspects, literature review, as well as the structure of mathematical documents in Brazil and Paraguay will be presented.

\section{High school reform in Brazil}

The NCCB was foreseen in the Constitution for Elementary Education and expanded in the National Education Plan (PNE) for Secondary Education with the intention of re-elaborating and signifying Brazilian Basic Education. With your approval:

[...] education networks and private schools will face the task of building curricula, based on the essential learning established, thus moving from the propositional normative plan to the action plan and curriculum management that involves the entire set of decisions and actions defining the curriculum and its dynamics (Brasil, 2017, p. 20).

Based on these constitutional frameworks, in item IV of art. 9 of the LDB, it is stated that:

[...] it is up to the Union to establish, in collaboration with the States, the Federal District and the Municipalities, competencies and guidelines for Early Childhood Education, Elementary Education and Secondary Education, which will guide the curricula and their minimum contents, in order to ensure common basic training (Brasil, 1996 apud Brasil, 2017, p. 10).

From this item, two key concepts for the development of the curricular issue in Brazil stand out, based on two notions considered fundamental: (1) what is common basic and what is not and (2) essential learning as a focus.

The first, already anticipated by the Constitution, establishes the relationship between what is basic-common and what is diverse in curricular matters: competences and guidelines are common, curricula are diverse. The second refers to the focus. By saying that curriculum content is at the service of skills development, it guides the definition of essential learning, and not just the minimum content to be taught (Brasil, 2017, p. 11).

With the prioritization of "skills" in the reform, through the proposal of the NCCB, with a more neotechnical bias (Silva, 2018), the document gives priority to the content as a "teaching management tool" (Macedo, 2018), essentially with a view to projecting student performance (Ball, 2010).

For the preparation of the NCCB, autonomous groups were formed and a complex procedure for sending suggestions for analysis and promotion of state debates. Once its "first version" was prepared, the NCCB was submitted to a public consultation, with most of the contributions being individualized, without undergoing a collective discussion process. Then, the systematization of contributions was analyzed by MEC and it was defined what would be incorporated into the document, thus originating its "second version". However, there was no specification of the parameter used for the choices.

Similarly, the "second version" of the NCCB has been published. This time, coordinated by the Union of Municipal Education Directors (Undime) and by the National Council of Education Secretaries (Consed), for which seminars were being organized 
throughout the country, following the same principle of participation. The document was presented by curriculum components and the participants, now in specific groups, positioned themselves based on what was shown to them.

Aguiar (2018) states that the process persisted in its tenuous form of participation, with a vertical, linear and centralized production methodology. With the formalization of a Management Group, MEC defined which contributions would be accepted. Thus, the "third version" originated, presented to the CNE for analysis.

Presenting a substitute discourse of the single curriculum model for an allegedly diversified and flexible one, the High School Reform was instituted through Law No. 13.415 / 2017, sent by means of a provisional measure to the National Congress. The LDB was changed by this measure, by which it was established, according to its art. 36 , that the curriculum will be composed by the NCCB and by "training itineraries, which should be organized by offering different curricular arrangements, according to the relevance to the local context and the possibility of the education systems" (Brasil, 2018, p. 467).

This change has been the subject of controversies and political pedagogical perspectives. With a view to guaranteeing the right to education, these propositions were redirected through regulatory policies under the privatist bias, and not in the search for the realization of the PNE (2014-2024) through federative articulation, the institutionalization of the National System of Education and the resizing and articulation of the role of the State. Regarding the NCCB of High School, especially its third version, with a strong emphasis on Portuguese Language and Mathematics, the idea of competency-based learning was reinforced, with a restrictive curriculum design and strongly linked to the standardized type assessment (Dourado \& Oliveira, 2018).

Regarding mathematical competences in high school, in studies such as that of Campos \& Vega (2010, p. 49) it is warned that "The foundation of the curriculum would pass, firstly, through a debate with the participation of multiple actors, which allows to establish which general and specific competences of the discipline one wants to reach in the students at the end of the high school educational process".

According to art. 35 of LDBEN, High School in Brazil has as general objectives:

I. The consolidation and deepening of the knowledge acquired in elementary education, enabling the pursuit of studies; II. basic preparation for the work and citizenship of the student, to continue learning, in order to be able to adapt flexibly to new conditions of occupation or further improvement; III. the improvement of the student as a human person, including ethical training and the development of intellectual autonomy and critical thinking; IV. understanding the scientifictechnological foundations of production processes, relating theory to practice in the teaching of each discipline (Brasil, 2017, p. 24).

In the NCCB in the area of Mathematics and its Technologies for Secondary Education, consolidated in 2018, the focus is on building an integrated view of Mathematics, applied to reality, to "promote actions that stimulate and provoke their processes of reflection and of abstraction, which support creative, analytical, inductive, deductive and systemic ways of thinking and which favor decision-making guided by ethics and the common good" (Brasil, 2018, p. 518).

Already manifested in the models from which they were generated, the concessions are reinforced by the documents with the ideas of competences and learning rights present in the texts of the curricula of Chile, Australia and the United States. The logic of a curriculum for learning objectives predominates, based on "[...] principles that, furthermore, still constitute the French imagination, perhaps Illuminist was not the North American insistence on concrete belonging" (Macedo, 2014, p. 897).

Therefore, the capital points are conceived by the objects of knowledge and the skills in the prescriptions of the document for the development of supposedly fundamental mathematical skills.

The Mathematics for High School document ends with the item "Considerations on Curricular Organization at NCCB". In this, it is prescribed that, in addition to the organization of skills by competencies, they can be arranged in the preparation of curricula in thematic units, bringing only the example on the study of polynomial functions (Brasil, 2018).

Other thematic units may be organized, bringing together both the skills defined in this NCCB and others that are necessary and that contemplate specificities and demands specific to the education systems and schools. However, it is essential to preserve the basic ideas of this NCCB regarding the articulation between the various fields of Mathematics, with a view to building an integrated view of Mathematics and applied to reality. In addition, it is essential to ensure that students have the specific competences and skills related to their processes of reflection and abstraction, which support creative, analytical, inductive, deductive and systemic ways of thinking and which favor ethical decision-making and the common good (Brasil, 2018, p. 535).

The expositions regarding the curricular organization bring the perspective of reductionism when prescribing examples of approaches in only one thematic unit and, next, present the perspective of opening the teaching systems associated with a supposedly reflective mathematical abstraction and applied to reality in systematized processes that will favor ethical decisionmaking. Hence the question arises: hollows, are protagonists raised, or is there a technical character due to the lack of guidelines that support the perspective of approaches from curricular organizations in specific contexts?

\section{The reform of the mathematics program for high school in Paraguay}

There is still no integrated system of standards for competences in Paraguay, by which it is determined what to teach, what are the appropriate levels of performance and resources, although in the curriculum documents the High School Competencies are prescribed with projection for content standards (Paraguay, 2009). 
In order to decentralize curricular decision-making, Ramón (2017) states that, since 2009, a list of national skills has been proposed by MEC. Their practices are an indicator of the elementary skills development that students need to have acquired by the end of High School. The proposed national capacities are complemented with others defined in each geographic department of the country and in each educational institution. Attends to the socio-cultural and economic peculiarities of each context in which the school is based and the emerging needs and characteristics are detected. Departmental capacities for High School have been established by most departmental education councils, however there is no indication of the institutional capacities that need to be established with the references of each educational community. Educational institutions are essential to determine the capabilities in its Institutional Strategic Plan. Such information is not found in its systematized and easily accessible form by the Ministry of Education and Culture, and / or even in its regional facilities.

In harmony with the general objectives of Education in Paraguay, in the general objectives of High School and the profiles of graduates of the level, set out in Law No. 1264/98, general competencies are established for this stage: over the three years, based on in the specific capacities offered by the subjects, students at this level should develop, among others, general skills, such as "Planning and solving problems with an ethical and critical attitude, using logical thinking and mathematical language, to formulate, deduce and make inferences that contribute to personal and social development" (Paraguay, 2016, p. 18).

It is argued by the MEC that, in Paraguay, a meticulous analysis was made of the various and complex concepts of competence and, due to the need to agree with one who guides curriculum development, as well as its implementation and evaluation, the following are pointed out concepts:

Competence: Integration of capacities (aptitudes, knowledge, skills and attitudes) to produce an efficient, logical and ethically acceptable operational act within the scope of the execution of a given role. Capacity: Each of the attitudinal, cognitive, dexterity and skills components that harmoniously articulated constitute the competence (Paraguai, 2013, p. 53-54).

In its common plan in the area of Mathematics and its technologies, the latest curricular update of the Scientific Baccalaureate of High School shows that its study is fundamental because it serves as an instrument for other areas. It is desired that the student, at this stage, be able to formulate and solve problematic situations taken from reality using new mathematical knowledge, emphasizing functional mathematics in a less abstract perspective, that is, with everyday applications. According to the program, in terms of innovation with respect to the previous proposals, the current document for Teaching Mathematics in High School:

[...] presents a distribution of capacities related to Trigonometry, Analytical Geometry and Algebra over the period between the 1st and 2nd courses of High School. This aims at the procedural development of the various questions presented and their subsequent assimilation and application, in order to achieve the effective development of the proposed capacities. The third year is dedicated exclusively to the development of capacities corresponding to Differential Calculus, always aiming at a reflective study of the different topics covered (Paraguai, 2016, p. 58).

In the Mathematics and its Technologies Program in Paraguay, only one specific competence of the discipline is presented "Formulating and solving problematic situations that involve the use of mathematical concepts, operations, theorems and properties of Algebra, Trigonometry, Analytical Geometry and Differential Calculus, applied to the modeling of reality situations (Paraguay, 2016, p. 59) - and a series of mathematical skills to be developed across the nation over the three years of High School is listed.

The document closes with the session "Guidelines for capacity development". Mathematical modeling is focused on as a way to achieve the learning of useful, practical and applicable Mathematics to special situations. The program suggests that the problems raised are extracted from real contexts, from situations that are attractive to students. Thus, they will care about the research, seeking to deepen the different topics covered. It is desired that the classes taught respond to practical and experimental mathematics, which can be developed inside and outside the classroom.

In case of impossibility of simulating situations or visualization in a real way, it is highlighted that it is essential to focus on the use of mathematical knowledge in different areas of the Middle level, such as Physics, Economics or Statistics and for current professions, such as Computer Science and Engineering.

Another very important point is the need to create spaces and situations in which students can formulate problems and share them among colleagues to be solved with the tools learned. For this, clear criteria must be established to be taken into account in the formulation, for example, that they have all the necessary data to be resolved and that the statement of each situation is clear and unambiguous. With the various applications currently offered by the technological world, mathematics classes cannot be left out of them. Whenever possible, computer programs should be searched in which students can exercise themselves in the application of learned algorithms and, at the same time, reinforce the contents studied in a more pleasant way than that which involves the use of paper and pencil (Paraguai, 2016, p. 63).

According to the program, evaluation in High School should take advantage of different instruments, harmoniously and coherently, between the methodology, the evaluation and the results obtained. In addition, it should not be limited to assessments by written tests, but emphasize the importance of oral presentations to measure the level of interpretation of students for different mathematical concepts.

Román (2017) highlights the efforts of the Ministry of Education and Culture to apply the skills approach in High School, particularly in the discipline of Mathematics, through the recent curricular reforms in Paraguay. The author considers that the curricular adaptations were made according to the paradigms of current and global education aiming at the improvement of 
didactic practices, showing that a majority sector considers that the new approach led to improvements in the classroom. However, due to the complexity of the model, efforts from teachers and students are required, which causes resistance.

\section{Explanatory Phase}

\section{Analysis of high school reform in Brazil}

When discussing the NCCB, Carvalho and Lourenço (2018) point out that the experts silence the voices of teachers in a game in which a stimulus to their participation comes with the purpose of, making them speak, to legitimize their speech. Thus, under an illusory participation, they are kept in consultation, but without effective decision-making power over vertically imposed models.

NCCB's position in the area of Mathematics is rather hollow. For Passos and Nacarato (2018, p. 131), "mistakes and reductionisms" are presented. The document raises an education for adaptation in a market logic (Seabra, 2015), ultraneoliberal, which disregards the teaching vision and protagonism, respectively, in the construction procedures and in the implementation of the reform.

Venco and Carneiro $(2018$, p. 7) state that the NCCB will be an instrument for the "adoption of a neoliberal project for education, which pursues international demands focused on the logic of measuring results and worldwide standardization of education". For Silva (2018), in the view of neo-technical pedagogy, there is control - over directors, teachers and students through the evaluation of international performance standards, in addition to accountability and payment techniques for meritocracy, combined with privatization. Such elements, when implemented, are supposed to guarantee quality in the provision of education. According to Ball (2014, p. 222):

[...] at the interface between educational policy and neoliberalism, money is everywhere. As I indicated, politics itself is now bought and sold, it is a commodity and an opportunity for profit, there is a growing global market for policy ideas. Policy work is also increasingly being outsourced to for-profit organizations, who bring their skills, speeches and sensitivities to the field of politics, for an honorary fee or a contract with the State.

For Passos and Nacarato (2018, p. 132), "although the reference matrix for external evaluations is not intended to guide what should be taught in schools, the tension caused by the imposition of a common curriculum, strengthened by the 'offer of lesson plans', for certified 'teacher training' from the business sector, indicates a worrying scenario".

Through the process of building the NCCB, the action of an international agenda to empty the concept of area and skills is reinforced, becoming items of external evaluation and reinforcing, under the logic of performance (Ball, 2010), that the curricula are increasingly prescriptive and subject to economic principles. The curriculum and evaluation become structures of political control, because, for Pacheco (2000, p. 13), quality evaluation becomes "the dominant discourse that serves as to legitimize State intervention in the process of regulating the system, as to hold schools, teachers, students and parents responsible for the results obtained".

Passos and Nacarato (2018, p. 120) affirm that, "undoubtedly, the context is complex and requires resistance movements, aiming to oppose the imposed models of mathematics education and teaching and based on reflective practices that aim professional autonomy and ethical commitment to the training of students". Therefore, the great challenge for teachers and researchers is to consider research, production and teaching as three inseparable dimensions, regardless of context and temporality. There is a need for the teacher to appropriate the contributions derived from research to resist. In this sense, D'Ambrósio and Lopes (2015, p. 11) warn that they:

[...] have presented diversified productions, which express multiple discourses, which contribute to a rethinking of the teaching and learning process that can be resized by the results of research on Problem Solving, Mathematical Modeling, Ethnomathematics, History and Philosophy of Mathematical Education, Technologies in Education Mathematics ... However, the contributions of these investigations are rarely incorporated into educational actions, as public policies and / or the determinations of educational institutions restrict the attitudes of the professionals who work in them. Many of the laws and guidelines determined by these private or governmental bodies reproduce guidelines arising from an educational system with outdated principles and which did not consider the current reality, do not respect the right of children and young people to learn in dialogue with the different socio-cultural context and political in which they were born and live.

Restricting the attitudes of Mathematics Education professionals also prevents the approach, through investigations carried out in the area, from reaching teachers and in their view on the construction of reforms. They have silenced their voices in pseudodemocratic processes classified as "modern and participatory". The complexities of this relationship create impacts on teaching practice and, therefore, in the construction and implementation of the "new curricula".

\section{Analysis of the reform of high school in Paraguay}

Ortiz (2012, p. 86) signals that:

[...] the quality of learning (and therefore teaching) in Paraguay is far from a competitive standard. A series of standardized tests were implemented during the first decade of 2000 to assess the quality of education, of which 2006 included a sample of the national reach of young people in the second year of High School. 
Complementing, Portillo e Paradeda (2016, p. 15) say that:

[...] the absence of spaces for reflection and critical analysis of educational policies, both academically and professionally, has not helped Paraguay to build discourses and alternative proposals to the dominant educational policies. Although there is a criticism of educational policy and, specifically, guidelines in the field of evaluation, it was not possible to build a different view that contrasts with the objectives and approaches outlined in current policies. Therefore, among the challenges, we can mention the need for the participation of educational organizations in the construction of a national educational evaluation policy. It is necessary to build comprehensive assessment systems that consider knowledge, assess specific skills and abilities, incorporate quantitative and qualitative elements and generate assessments that take into account the particularities in which education in different regions of the country and do not reduce them to standardized tests.

Regarding the recent curricular reforms of Mathematics in Paraguay, in the appraisals and in the literature review of the documents, it is shown that educational policies must admit the construction of permanent spaces for dialogue and new mechanisms of agreement. According to Palamidessi (2003, p. 27), "The development of dialogues, research and comparative studies of different experiences, with the participation of different actors, is a practice that must be promoted and expanded". Eliás (2017, p. 23), in turn, signals that:

In the Paraguayan case, this process is of great need at present, where, it seems, certain basic agreements or consensus have been weakened on the objectives and scope of education policies. Although, at the beginning of the reform, there was an expectation of democratic construction, in which education had a central role in the development of a democratic and pluralistic citizenship, today, this perspective has been modified and has acquired other contents and orientations. Global education policies and the growing regional conservatism impose a technocratic look, focused on building human capital, generating reductionism in terms of education objectives and results.

These results are measured in terms of academic performance (Ball, 2010, 2014) only in certain areas of knowledge, losing sight of the cultural and historical contexts in which the educational experience is developed. Also, according to the author, it is essential to develop a systematic initiative for reflection and discussion of educational policies at national level, including with the different sectors and organizations involved in the review and formulation of a new educational policy.

Specifically, on the Mathematics Program, Román (2017) highlights the institutional difficulties in the implementation of curricular guidelines, coinciding with the need for more teacher training, as well as permanent advice from the responsible bodies and the need to resume the debate to be reintegrated in High School in Paraguay on the competency curriculum. All of this through a general assessment of the implementation process.

The Mathematics Program revolves around skills combined with planning and problem solving, so that the student can take on a functional Mathematics with a focus on modeling real situations, taking into account a globalized point of view for the area and which has raised resistance by part of the teachers.

\section{Juxtaposition Phase}

The investigation was constituted by the analysis of the contexts of Ball's influence and production (2004) in the different contexts of document reforms. The analytical categories emerged from the contexts of influence and context of text production that are part of Ball's policy cycle (2004) with the intention of understanding the associated political processes and intentionalities and revealed in the recent curricular reforms carried out in Brazil and Paraguay. The following is a summary of the power lines and critical points of the Mathematics documents in each context of reform.

\section{High school document in Brazil for the area of mathematics and its technologies}

1- Power lines: An inaccurate and quick position regarding the area is exposed at the Mathematics NCCB. It brings, without justification, certain contents and skills in the thematic units, nor methodological indications for the approaches.

2- Critical Points: An education for adaptation is signaled, that is, an educational guideline for the market, thinking about producing evaluations; an ideology and an education model conceived as a commodity (Seabra, 2015) with a predominance of matrices of skills to be fulfilled by the teacher.

Thus, Passos and Nacarato (2018, p. 130 apud Freitas, 2014, p. 1087) corroborate, which warn that "[...] a new version of technicism or neotechnics is back: just learn to do, without need for professional knowledge for such".

\section{High school document in Paraguay for the area of mathematics and its technologies}

1- Power Lines: With respect to the Paraguayan program, it focuses on a specific competence presenting the perspective of problem solving by modeling real situations.

2- Critical Points: The updates of the Mathematics programs were consolidated in accordance with the standards of current and global education, such as the teaching management (Macedo, 2018). Essentially, the aim is to project the performance of High School students (Ball, 2010).

\section{Comparative Phase}

Intending to elucidate the parities and specificities through the contextual factors of influence and production (Ball, 1994) of the above-mentioned Mathematics for High School documents (Ferrer, 2002; Pilz, 2012, 2016), it is exposed, in Table 2, the 
Table 2. Parities and specificities in the curricular reform contexts of the Mathematics for High School programs in Brazil and Paraguay

\begin{tabular}{|c|c|c|c|}
\hline \multirow[t]{2}{*}{ CATEGORIES } & PARITIES & \multicolumn{2}{|l|}{ SPECIFICITIES } \\
\hline & $\Leftrightarrow$ & $\Leftrightarrow$ & b \\
\hline INFLUENCE CONTEXTS & $\begin{array}{l}\text { Influences of the North American and } \\
\text { Australian curricula, PISA, OECD, foundations } \\
\text { and philanthropic institutions. }\end{array}$ & & \\
\hline $\begin{array}{l}\text { PRODUCTION } \\
\text { CONTEXT }\end{array}$ & $\begin{array}{l}\text { Autonomous teams for preparation, } \\
\text { Reductionism and focus on competences. }\end{array}$ & Five specific skills for high school. & $\begin{array}{l}\text { Only a specific competence for } \\
\text { High School. }\end{array}$ \\
\hline POWER LINES & $\begin{array}{l}\text { Emptying of advances already achieved in the } \\
\text { area of Mathematics Education. }\end{array}$ & $\begin{array}{l}\text { Vacant position in relation to the } \\
\text { area. It brings certain contents and } \\
\text { skills, but there is neither } \\
\text { justification nor convincing } \\
\text { discussion in the thematic units. }\end{array}$ & $\begin{array}{l}\text { Focus on less mathematical } \\
\text { abstract and more functional } \\
\text { applications. } \\
\text { Differential Calculation } \\
\text { Approach. }\end{array}$ \\
\hline CRITICAL POINTS & $\begin{array}{l}\text { Proposal configured as ultraneoliberal and neo- } \\
\text { technician, where the contents are treated as } \\
\text { teaching management instruments and with a } \\
\text { focus on performances and rankings. It fulfills } \\
\text { an agenda to empty the debate about the } \\
\text { area's conception. Focus on education for } \\
\text { adaptation, directed to the market and results } \\
\text { in the rankings of external evaluations. }\end{array}$ & & \\
\hline
\end{tabular}

Source: The author

summary of the analyzes carried out in the previous sessions. This is done through divisions considered expressive for comparing the contexts and discourses of curriculum reforms in mathematics in these countries.

Through this comparative study, parities and specificities were confirmed regarding the interventionism of entities in the development processes of curricular reforms, the lines of force presented in the prescriptions and the critical points of the most recent reforms in the countries, even at political moments and specific contexts of curriculum reforms.

The similarities related to the critical points of the reforms in the countries allowed to point out some trends that revolved around international agencies and the participation of multilateral organizations, reductionism and focus on competences to meet the varied demands of the globalized world, silencing the voices of societies and participation of teachers by public consultation without clear criteria, and neo-technical and ultra-liberal perspectives, highlighting performativity (therefore, the rankings of external evaluations).

Specifically, there was a greater number of specific skills prescribed for High School in Brazil, to the detriment of content presented without plausible justification. In Paraguay, High School brings a focus on more functional mathematics with a focus on Mathematical Modeling and also prescribes Differential and Integral Calculus in this teaching stage, absent in the curriculum prescribed for Brazilian High School.

\section{CONCLUSIONS}

Through the analysis of the contexts of influence and production, members of the Policy Cycle proposed by Ball (1994), of the phases of the Comparative Education methodology summarized by Pilz (2012) and through the literature review, it was proved that the production from NCCB in Brazil and the last update of the Mathematics Program (2016) in Paraguay are configured in approved prescriptions for High School seen as political texts resulting from tensions, disputes and agreements. Groups active in different sectors of the production of texts compete to control representations of politics (Mainardes, 2006, 2018).

Popularity was gained by new voices and nodes of interest in the process of reforming the mathematics curricula in these countries, being represented in their processes and political contexts (Ball, 2013) by groups and organizations with apparent influences and a tendency to comply with processes that are part of a international reform agency (Ball, 1994, 2013; Passos \& Nacarato, 2018).

The reforms on skills that can serve a management model are taking place (Macedo, 2014), focusing primarily on performativity (Ball, 2010, 2014), with prescriptions marked as a solution to the problems of mathematics education in these countries (Avelar \& Ball, 2017). However, they are surrounded by turbulent processes in which the layout of the curricular proposals was apparently democratic, but which simulate vertically established models (Carvalho \& Lourenço, 2018)

Based on what was evidenced in the present investigation, the voice of teachers (historically responsible for research relevant to and for the improvement of teaching and for the democratization of access to mathematical knowledge in different contexts) in these elaboration processes was silenced. Certainly, the debate does not end here. There will also be many tensions linked in the context of teacher training and practice and the results caused by curriculum reforms in the contexts of those countries.

The importance of hybridizing part of Ball's policy cycle (2004) and the stages of Pilz's comparative method (2012) for this study is highlighted, as well as the constant need to preserve the conceptual and epistemological foundations of Comparative Education in the sphere of Mathematics Education. 
As Campos and Vega (2010), it is reinforced that, at least in Mathematics, a skills approach would express that the individual can be more qualified to analyze what is offered by the environment, who can decide with better elements of judgment between different options and, in general, be more critical related to the demands in an increasingly globalized world. A competency approach in High School, as far as it is concerned, would require considering several elements, for example, the basis of the curriculum, the curricula and their characteristic programs, the development of the lesson and assigned tasks, the evaluation and the initial and continued training of teachers.

Author contributions: All authors have sufficiently contributed to the study, and agreed with the results and conclusions.

Funding: No funding source is reported for this study.

Declaration of interest: No conflict of interest is declared by authors.

\section{REFERENCES}

Aguiar, M. Â. (2018). da S. Report of resistance to the institution of NCCB by the National Education Council upon request of view and explanations of votes. In M. A. D. S. Aguiar \& L. F. Dourado (Eds.), NCCB against the PNE 2014-2024: evaluation and perspectives.

Arnove, R. F. (2012). World-systems analysis and comparative education in the era of globalization. In R. Cowen, A. M. Kazamias, \& E. Ulterhalter (Eds.) Comparative education: International panorama and perspectives (vol. 1, pp. 131-152). UNESCO / CAPES.

Avelar, M., \& Ball, S. (2017). Mapping new philanthropy and the heterarchical state: The mobilization for the national learning standards in Brazil. International Journal of Educational Development, 64,65-73. https://doi.org/10.1016/j.ijedudev.2017.09.007

Ball, S. J. (1994). Education reform: A critical and post structural approach. Open University Press.

Ball, S. J. (2004). Performativity, privatization and the post-state of social welfare. Educação \& Sociedade, Campinas, 25(89), 11051126. https://doi.org/10.1590/S0101-73302004000400002

Ball, S. J. (2010). Performativities and fabrications in educational economics: Towards a performative society. Revista Educação \& Realidade, 35(2), 37-55.

Ball, S. J. (2013). New states, new governance and new educational policy. In M. W. Apple; S. J. Ball \& L. A. Gandin (Eds.), Sociology of Education: International analysis. Penso.

Ball, S. J. (2014). Educação global S.A.: new political networks and the liberal imagination. Editora UEPG.

Brasil (1996). Ministry of Education. LDB - Leis de Diretrizes e Bases. Law no. 9.394.

Brasil (2017). Ministry of Education. Base Nacional Comum Curricular (NCCB). Elementary School.

Brazil (2018). High School in the context of Basic Education: The area of Mathematics and its Technologies. In National Common Curricular Base (NCCB). http://basenacionalcomum.mec.gov.br/abase/\#medio/a-area-de-matematica-e-suas-tecnológicas

Campos, H. B., \& Vega, J. A.A. (2010). Competencias matemáticas en la Enseñanza Media [Mathematical competences in secondary school]. Cuadernos de Investigación y Formación en Educación Matemática, 5(6), 39-62.

Carvalho, J. M., \& Lourenco, S. G. (2018). The silencing of Basic Education teachers by the strategy of making them speak. ProPosições, Campinas, 29(2), 235-258. https://doi.org/10.1590/1980-6248-2017-0007

Corrêa, A., \& Morgado, J. C. (2018). The construction of the National Common Curricular Base in Brazil: tensions and challenges. Proceedings of the IV COLBEDUCA - Luso-Brazilian Colloquium on Education. v. 3, 1-12.

D'Ambrosio, B. S., \& Lopes, C. E. (2015). Creative Insubordination: an invitation to the reinvention of the mathematical educator. Bolema, Rio Claro, 29(51), 1-17. https://doi.org/10.1590/1980-4415v29n51a01

Dias, M. O. (2016). Trends in mathematics education: Brazilian and Paraguayan curricular paths (1st ed.), Appris.

Dourado, L., \& Oliveira, J. (2018). National Common Curricular Base (NCCB) and the Impacts on Higher Education Regulation and Evaluation Policies. In M. Aguiar \& L. Dourado (Eds.), NCCB against the PNE 2014-2024: evaluation and perspectives (pp. 38-43). ANPAE.

Eliás, R. (2017). El desafío de la construcción de la participación em la política educativa del Paraguay. Centro de Análisis y Difusión de la Economía Paraguaya, CADEP, Asunción - Paraguay.

Ferrer, J. (2002). La Educación Comparada actual. Barcelona, Ed. Ariel.

Freitas, L. C. (2014). Education business reformers and the dispute over control of the pedagogical process at school. Educação \& Sociedade, Campinas, 35(129), 1085-1114. https://doi.org/10.1590/ES0101-73302014143817

Gonçalves, H. J. L., \& Pires, C. M. C. (2015). Meta-Analysis of Comparative Studies on Latin American Mathematics Curricula. Proceedings of the VI International Seminar on Research in Mathematics Education (SIPEM).

Macedo, E. (2014). Common curriculum base: new forms of sociability producing meanings for education. E-curriculum, 12(3), 1530-1555.

Macedo, E. (2018). "The base is the base". And what is the curriculum? In M. Â. Aguiar \& L. F. Dourado (Eds.), NCCB against the PNE 2014-2024: evaluation and perspectives.

Macedo, R. S. (2002). Critical and multi-referential ethnosearch in the humanities and education. EDULFA. 
Mainardes, J. (2006). The policy cycle approach: a contribution to the analysis of educational policies. Educação \& Sociedade, Campinas, 27(94), 47-69. https://doi.org/10.1590/S0101-73302006000100003

Mainardes, J. (2018). The policy cycle approach: Exploring some challenges of its use in the field of Educational Policy. Journal of Educational Policies, 12(16).

Nóvoa, A (2009). Comparative education analysis model: the field and the map. In: D. B. de Souza \& S. A. Martins (Eds.), Comparative education: Overseas routes (pp. 23-62). Shaman.

Organization for Economic Cooperation and Development (OECD). (2018). The Future of Education and Skills Education 2030. Paris, France. https://www.oecd.org/education/2030/E2030\%20Position\%20Paper\%20(05.04.2018).pdf

Ortiz, L. (2012). Reforma educativa y conservación social. Aspectos sociales del cambio educativo em Paraguay [Educational reform and social conservation. Social aspects of educational change in Paraguay]. Revista Latinoamericana de Estudios Educativos, 55-90.

Pacheco, J. A. (2000). Curricular flexibility: some questions. In J. A. Pacheco (Ed.), Curriculum integration policies (pp. 127-145). Porto Editora.

Palamidessi, M. (2003). Sindicatos docentes y gobiernos: Conflictos y diálogos en torno a la Reforma Educativa en América Latina [Teacher Unions and Governments: Conflicts and Dialogues Around the Education Reform in Latin America], Preal.

Paraguai (1998). Ley General de Educación No 1264/98 [General Education Law No. 1264/98]. Gaceta Oficial del Paraguay.

Paraguai (2009). Ministerio de Educación y Cultura. Valoración de los aprendizaje para la promoción de estudiantes de la Educación Media [Ministry of Education and Culture. Appreciation of learning for the promotion of students of Secondary Education]. Asunsion.

Paraguai (2013). Ministerio de Educación y Cultura. Desarrollo de Capacidades en la Educación Media [Ministry of Education and Culture. Capacity Development in Secondary Education]. Asunsion.

Paraguai (2016). Ministerio de Educación y Cultura. Actualización Curricular del Bachillerato Científico de la Educación Media - Plan Común: Matemática y sus Tecnologías [Ministry of Education and Culture. Curricular Update of the Scientific Baccalaureate of Middle Education - Common Plan: Mathematics and its Technologies]. Asunsion: MEC.

Passos, C. L. B., \& Nacarato, A. M. (2018). Trajectory and perspectives for teaching mathematics in the early years. Advanced Studies, 32(94), 119-135. https://doi.org/10.1590/s0103-40142018.3294.0010

Pilz, M. (2012). International comparative research into vocational training: methods and approaches. In M. Pilz (Ed.), The future of vocational education and training in a changing world (pp. 561-588). Springer. https://doi.org/10.1007/978-3-531-18757-0_30

Pilz, M., Krisanthan, B., Michalik, B., Zenner, L., \& Li, J. (2016). Learning for life and/or work: The status quo of pre-vocational education in India, China, Germany and the USA. Research in Comparative \& International Education, 11(2), $117-134$. https://doi.org/10.1177/1745499916637173

Portillo, A., \& Paradeda, M. (2016). Tensiones de los gremios docentes y las políticas de Evaluación estandarizada en Paraguay [Tensions of the teaching unions and standardized assessment policies in Paraguay]. XI Seminario Internacional de la Red Estrado - Movimientos Pedagógicos y Trabajo Docente en tiempos de estandarización [XI International Seminar of the Estrado Network - Pedagogical Movements and Teaching Work in times of standardization].

Román, J. D. M. (2017). El enfoque de competencias en el currículo de Matemáticas de la Educación Media. La perspectiva docente sobre su implementación [The competence approach in the High School Mathematics curriculum. The teaching perspective on its implementation]. Revista Internacional de Investigacion en Ciencias Sociales, 13(1), 14-24. https://doi.org/10.18004/riics.2017.julio.14-24

Seabra, F. (2015). Loan of curriculum policies in Portugal - 2011-2014. In J. C. Morgado, G. M. Lunardi Mendes, A. F. Moreira, \& J. A. Pacheco (Eds.), Curriculum, Internationalization and cosmopolitanism: Contemporary challenges in Luso-Afro-Brazilian contexts (Vol. I, pp. 79-90). DeFacto Editores.

Sharma, S. (2013). Qualitative approaches in mathematics education research: challenges and possible solutions. Education Journal, 2(2), 50-57. https://doi.org/10.11648/j.edu.20130202.14

Silva, A. V. M. (2018). Neotechnics - the Resumption of Technicism in New Bases. Revista de Ensino, Educacao e Ciencias Humanas, 19(1), 10-16. https://doi.org/10.17921/2447-8733.2018v19n1p10-16

Venco, S. B., \& Carneiro, R. F. (2018). "For those who are going to work at the fair ... this education is too good": the educational policy to support the division of classes. Horizontes, Bragança Paulista, 36(1), 7-15. https://doi.org/10.24933/horizontes.v36i1.660

Villalobos Torres, E. M., \& Trejo Sánchez, C. M. (2015). Fundamentos teórico metodológicos para la educación comparada. In M. A. Navarro Leal \& Z. Navarrete Cazales (Eds.), Educación comparada: internacional y nacional (pp. 19-27). Plaza y Valdes Editores. 